\title{
Aude Fauvel, La voix des fous. Hector Malot et les romans d'asile, «Romantisme» $\mathrm{n}^{\circ} 141$
}

\section{Ida Merello}

\section{Q OpenEdition}

1 Journals

\section{Edizione digitale}

URL: http://journals.openedition.org/studifrancesi/8034

DOI: ERREUR PDO dans /localdata/www-bin/Core/Core/Db/Db.class.php L.34 : SQLSTATE[HYO00]

[2006] MySQL server has gone away

ISSN: 2421-5856

\section{Editore}

Rosenberg \& Sellier

\section{Edizione cartacea}

Data di pubblicazione: 1 juillet 2009

Paginazione: 431

ISSN: 0039-2944

\section{Notizia bibliografica digitale}

Ida Merello, «Aude Fauvel, La voix des fous. Hector Malot et les romans d'asile, «Romantisme» n 141 », Studi Francesi [Online], 158 (LIII | II) | 2009, online dal 30 novembre 2015, consultato il 07 janvier 2021. URL: http://journals.openedition.org/studifrancesi/8034; DOI: https://doi.org/ERREUR PDO dans / localdata/www-bin/Core/Core/Db/Db.class.php L.34 : SQLSTATE[HY000] [2006] MySQL server has gone away

Questo documento è stato generato automaticamente il 7 janvier 2021.

\section{(c)}

Studi Francesi è distribuita con Licenza Creative Commons Attribuzione - Non commerciale - Non opere derivate 4.0 Internazionale. 


\title{
Aude Fauvel, La voix des fous. Hector Malot et les romans d'asile, «Romantisme» $\mathrm{n}^{\circ} 141$
}

\author{
Ida Merello
}

\section{NOTIZIA}

AUDE FAUVEL, La voix des fous. Hector Malot et les romans d'asile, «Romantisme» $\mathrm{n}^{\circ} 141$, 3/2008, pp. 51-64.

1 Oltre che autore per la gioventù, Malot è stato anche uno specialista di ospedali psichiatrici e di psichiatria, a tal punto da venire consultato in proposito in alternativa ai medici. Cavalcando un movimento contro i manicomi che lui stesso aveva contribuito a promuovere, scrisse con Un beau-frère il primo romanzo anti ospedalizzazione e capostipite di un genere letterario, quello dei «romans d'asile». L'A. esamina la fortuna editoriale del testo, ma anche la sua tecnica compositiva e la qualità stilistica, così efficaci sul piano politico da suscitare una commissione d'inchiesta e da incoraggiare molti a prendere la penna per denunciare situazioni di sopruso e di violenza. Malot dedica all'alienazione altri due volumi, Le Mari de Charlotte (1873) e Mère (1889), romanzo a chiave in cui si possono facilmente riconoscere alcuni medici e le loro teorie. L'A. mostra come lo stile si faccia sempre più aggressivo, e come lo scrittore si convinca che un pizzico di follia possa essere prezioso, raggiungendo così lo stereotipo di tutto il secolo, in cui l'equazione genio-follia è stata più volte ribadita. 